\title{
Fracaso de la osteosíntesis mandibular. Consideraciones biomecánicas y tratamiento. A propósito de dos casos clínicos
}

\section{Mandibular osteosynthesis failure. Biomechanical and therapeutic considerations. Two clinical cases}

\author{
I. Navarro', J.L. Cebrián², G. Demaría', M. Chamorro3, J.M. López-Arcas', J.M. Múñoz², \\ J.L. Del Castillo², M. Burgueño4
}

Resumen: Introducción: El fracaso de la osteosíntesis mandibular no es una situación frecuente. El objetivo de este artículo es determinar su etiología y esbozar su tratamiento.

Material y métodos: Se presentan dos casos clínicos en los que se produjo un fracaso de la osteosíntesis y se indica su tratamiento.

Discusión: Se analiza la etiología del fracaso y cómo, con la terapéutica adecuada, se consigue una regeneración ósea. Un conocimiento exacto de las características biomecánicas del sistema masticatorio, ayuda a abordar esta patología.

Conclusión: Una fijación rígida con placas tipo "lock" junto a injerto esponjoso autólogo de cresta iliaca es la clave del éxito terapéutico.

Palabras clave: Fracaso de la osteosíntesis; Placas bloqueadas; Injerto de cresta ilíaca.
Abstract: Introduction: Mandibular osteosynthesis failure is not common. The purpose of this article is to examine the etiology and treatment of mandibular osteosynthesis failure.

Material and methods: Two clinical cases of mandibular osteosynthesis failure and its treatment are reported.

Discussion: The etiology of osteosynthesis failure and bone regeneration with suitable treatment is analyzed Exact knowledge of the biomechanical characteristics of the masticatory system is useful in approaching this condition.

Conclusion: Rigid fixation with locking plates and autologous grafts of iliac crest cancellous bone are the key to therapeutic success.

Key words: Osteosynthesis failure; Locking plates; lliac crest graft.

Recibido: 15.10 .07

Aceptado: 28.01 .09

\footnotetext{
1 Médico Interno Residente

2 Médico Adjunto

3 Jefe Clínico

4 Jefe de Servicio

Servicio de Cirugía Oral y Maxilofacial.

Hospital Universitario La Paz. Madrid. España
}

\section{Correspondencia:}

Ignacio Navarro Cuéllar

Servicio de Cirugía Oral y Maxilofacial

Hospital Universitario La Paz

Paseo de la Castellana 264

28046 Madrid. España

E-mail: nnavcu@hotmail.com 


\section{Introducción}

El fracaso de la osteosíntesis mandibular por una fijación inadecuada es una más de las múltiples causas (infección, enfermedades sistémicas como la diabetes, consumo crónico de corticoides...) de la ausencia de consolidación de las fracturas mandibulares. ${ }^{1}$

En los últimos 50 años, el desarrollo de los métodos de fijación interna de las fracturas mandibulares, $y$, sobre todo, la idea de cirugía traumatológica como cirugía reconstructiva de la función, han revolucionado el tratamiento de los enfermos con traumatismos faciales y mandibulares.

Así, el objetivo a la hora de tratar las fracturas mandibulares es:2

1. Conseguir una reducción anatómica de la fractura.

2. Llevar a cabo una osteosíntesis estable para satisfacer las solicitaciones biomecánicas locales.

3. Conseguir una técnica quirúrgica poco traumática.

4. Movilización activa, indolora y precoz de los músculos y articulaciones adyacentes a la fractura.

Es necesario un conocimiento exacto de la anatomía mandibular y de las características biomecánicas del sistema músculo-esquelético masticatorio, íntegro y deteriorado, para reducir y realizar la ostesíntesis pertinente en una fractura mandibular.

A lo largo de la historia de la osteosíntesis, los diferentes autores han entendido de distinto modo estos aspectos, de manera que surgieron dos escuelas enfrentadas, los partidarios de una fijación absolutamente rígida (AO/ASIF) y los que abogaban por una fijación menos rígida, ${ }^{3}$ (escuela francesa).

Actualmente, ambas posturas se han conciliado al adecuar las exigencias de la osteosíntesis al estado que presenta el sistema traumatizado. Así, si éste es aceptable se le ofrece la posibilidad de compartir con la osteosíntesis la curación de la fractura, mientras que si es poco competente se confía totalmente en las placas y tornillos para lograr la consolidación de la ésta.

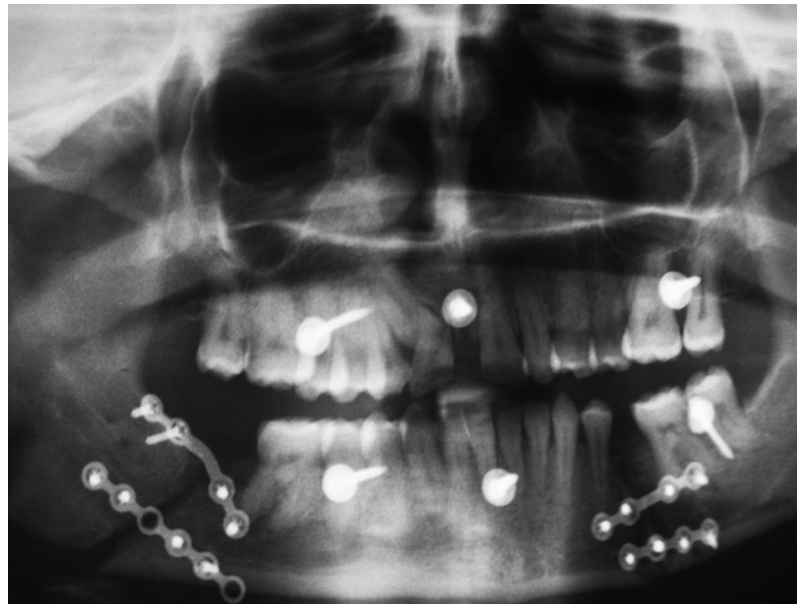

Figura 1. Ortopantomografía tras la primera cirugía.

Figure 1. Orthopantomography after the first operation.

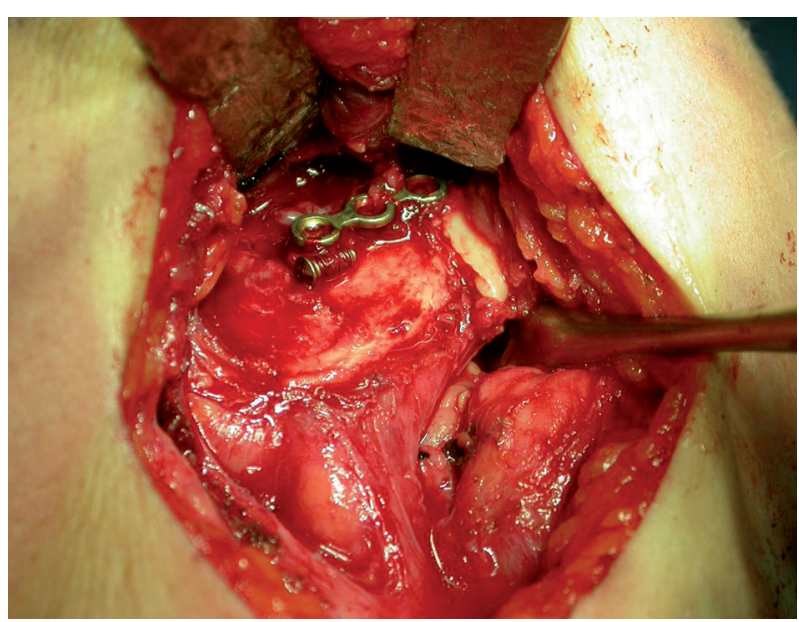

Figura 2. Abordaje extraoral. Se observa un tornillo completamente suelto.

Figure 2. Extraoral approach. A completely loose screw is visible.

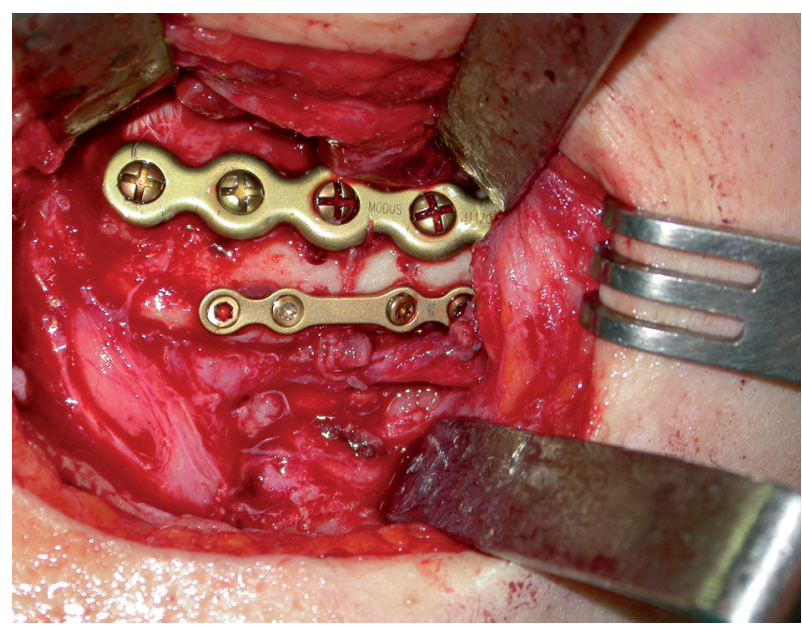

Figura 3. Osteosíntesis derecha en la segunda cirugía. Figure 3. Right osteosynthesis in the second operation.

\section{Introduction}

The failure of mandibular osteosynthesis due to inadequate fixation is one of several causes (infection, systemic diseases like diabetes, and chronic corticoid use) of poor mandibular fracture consolidation. ${ }^{1}$

In the last 50 years, the development of internal fixation methods for mandibular fractures and, especially, the idea that traumatology surgery should restore function have revolutionized the treatment of patients with facial and mandibular injuries.

The objective of the treatment of mandibular fractures is:2

1. Anatomically correct fracture reduction.

2. Stable osteosynthesis that satisfies local biomechanical demand.

3. Minimally traumatic surgical technique.

4. Active, painless, early mobilization of the muscles and joints adjacent to the fracture. Exact knowledge of the mandibular anatomy and biomechanical characteristics of the masticatory musculoskeletal system, whether intact or deteriorated, is required for reducing mandibular fractures and performing the necessary osteosynthesis.

Throughout the history of osteosynthesis, authors have held differing views on these parameters, which led to the development of two competing schools of thought, one in favor of absolutely rigid fixation (AO/ASIF) and the other in favor of less rigid fixation ${ }^{3}$ (French school).

These two positions have now been conciliated by the adaptation of osteosynthesis requirements to the status of the injured system. Consequently, 
Surgen así los conceptos de carga compartida y carga soportada. Una situación tipo carga soportada implica que el material de osteosíntesis sostiene todo la carga funcional, y supone dejar el foco en completo reposo para su cicatrización. ${ }^{4}$ Por el contrario, en una situación tipo carga compartida, el material ayudará a la mandíbula competente a mantener la carga funcional. Son situaciones en las que se persigue una fijación funcionalmente estable, permitiendo un leve movimiento en el foco.

Las situaciones de carga soportada son: fracturas conminutas, infectadas, cuando haya importante pérdida de partes blandas, fracturas en pacientes con mandíbula atrófica (edéntulos) y en fracturas con defecto de continuidad.

La fijación funcionalmente estable se aplica a fracturas simples y a osteotomías. ${ }^{5}$

En el presente trabajo se exponen dos casos clínicos en los que el fracaso de la osteosíntesis se debió a la falta de observación de estos principios básicos.

Se analizan las causas del fracaso y se propone el tratamiento que aseguró el éxito terapeútico.

\section{Casos clínicos}

\section{Caso 1}

Mujer de 24 años con síndrome de Down, que presenta una fractura bilateral de cuerpo mandibular por traumatismo facial de etiología desconocida. Se intervino en otro centro mediante la colocación de dos miniplacas en cada lado (Fig. 1).

Se abordó el foco del lado derecho por vía extraoral (reducción y osteosíntesis con placas de 2.5 de reconstrucción y 2.0 tipo "lock") y el foco izquierdo por vía intraoral con placas "lock" de 2.0 (Figs. 2 y 3). La paciente salió del quirófano sin fijación intermaxilar.

Cinco meses después presentó un nuevo fracaso de la osteosíntesis dcha (Fig. 4). Se practicó una nueva cervicotomía realizando una

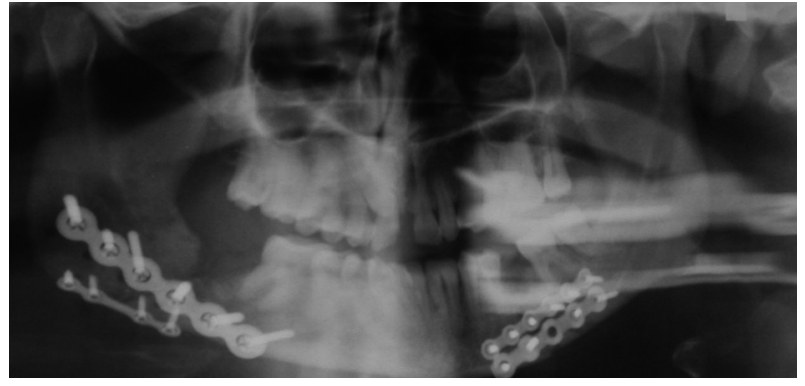

Figura 4. Ortopantomografía con el fracaso de la osteosíntesis mandibular derecha.

Figure 4. Orthopantomography showing failure of the right mandibular osteosynthesis.

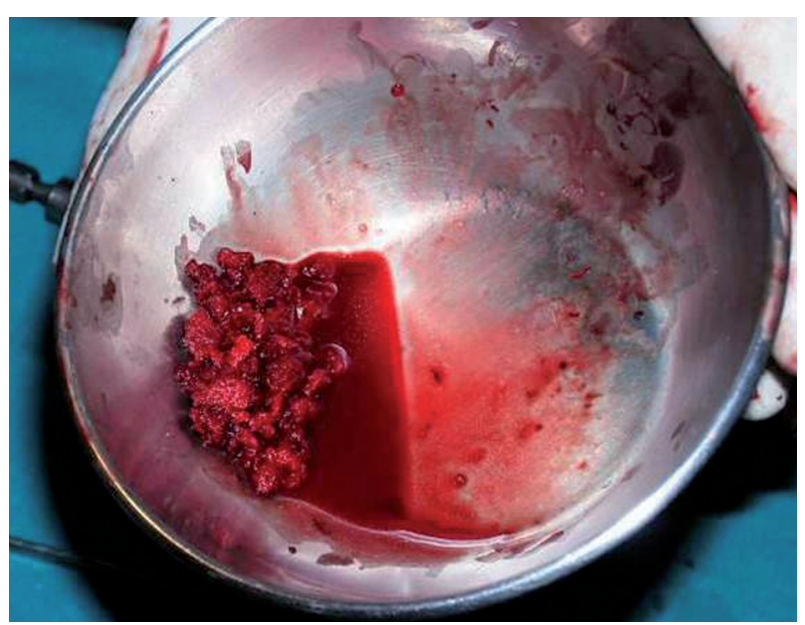

Figura 5. Chips de cresta ilíaca autóloga.

Figure 5. Chips of autologous iliac crest.

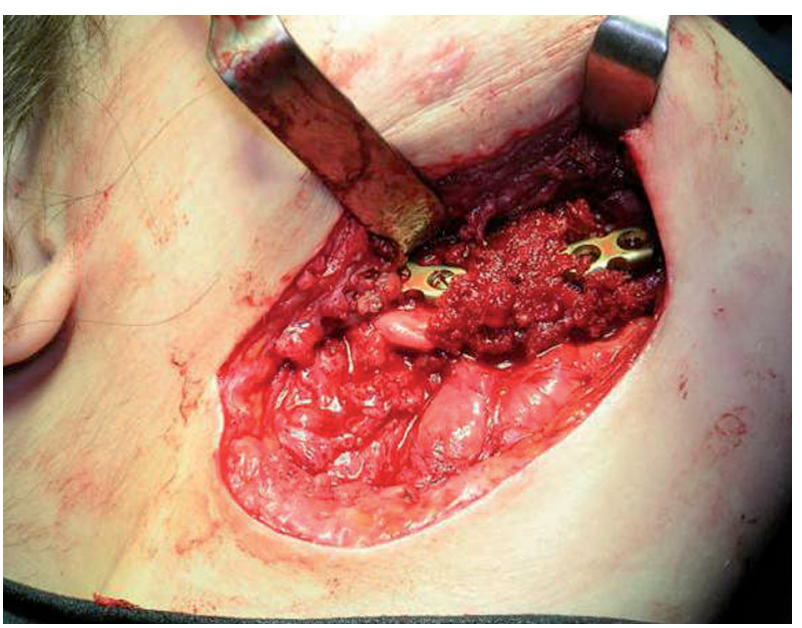

Figura 6. Chips y osteosíntesis con una placa de reconstrucción de $2,4 \mathrm{~mm}$.

Figure 6. Chips and osteosynthesis with a $2.4 \mathrm{~mm}$ reconstruction plate. if system status is acceptable, the system can contribute to fracture healing with osteosynthesis, but if the system status is deficient, fracture healing should be entrusted fully to plates and screws to achieve consolidation. The concepts of load sharing and load bearing arose from this view. A load-bearing situation is one in which the osteosynthesis material sustains the entire functional load and the fracture locus is allowed to heal in complete repose. ${ }^{4}$ In contrast, in a load sharing situation the osteosynthesis material helps the competent jaw to cope with the functional load. In these situations a functionally stable fixation is sought and slight movement of the locus is allowed. Examples of load bearing situations are: comminuted fractures, infected fractures, situations of major soft-tissue loss, fractures of an atrophic (edentulous) mandible, and fractures with loss of continuity.

Functionally stable fixation is used in simple fractures and osteotomies. $^{5}$

In the present study two clinical cases are reported in which the osteosynthesis failure resulted from overlooking these basic principles. The causes of osteosynthesis failure were analyzed and treatment to ensure therapeutic success was proposed.

\section{Clinical cases}

Case 1

A 24-year-old woman with Down's syndrome presented bilateral fracture of the mandibular body due to a facial injury of unknown etiology. She was intervened in another center to place two small plates on each mandible (Fig. 1).

The right fracture focus was approached extraorally (reduction and osteosynthesis with 2.5 reconstruction plates and 2.0 locking plates) and the left fracture focus was approached intraorally with 2.0 locking plates (Figs. 2 and 3). The patient left the operating room 
nueva osteosíntesis con una placa de reconstrucción tipo "unilock" 2.4. e injerto autólogo de cresta iliaca. La paciente salió del quirófano con un bloqueo intermaxilar elástico (Figs. 5 y 6).

Un año después de la segunda cirugía, la fractura está perfectamente consolidada. En la ortopantomografía de control se aprecia neoformación ósea (Fig. 7).

\section{Caso 2}

Mujer de 43 años de edad, exfumadora, sin otros antecedentes de interés. Presenta una fractura bicondílea intracapsular y de ángulo mandibular derecho (Fig. 8).

Se realizó osteosíntesis con dos miniplacas en el ángulo mandibular. Las fracturas de ambos cóndilos se trataron mediante bloqueo intermaxilar.

Tres meses más tarde presentó una pseudoartrosis en el ángulo mandibular derecho (Fig. 9). Se practicó un abordaje extraoral con retirada de placas, así como una nueva reducción y osteosíntesis con 2 placas tipo "lock" de 2.0 de distinto perfil asociado a injerto particulado esponjoso de cresta ilíaca (Figs. 10 y 11).

Seis meses después de la cirugía no tiene clínica sugestiva de fracaso de la osteosíntesis (Fig. 12).

\section{Discusión}

El viejo concepto de tratamiento de la fractura como aposición de los fragmentos óseos ha sido desterrado en la mayor parte de los campos de la traumatología.

En la introducción se plantearon cuatro objetivos del tratamiento de las fracturas mandibulares. Los dos primeros, la necesidad de reducción anatómica y la adecuación de la osteosíntesis a las características biomecánicas del sistema ya han sido esbozadas previamente.

En cuanto a los dos últimos objetivos, la técnica poco traumática y la rehabilitación precoz, constituyen dos de los pilares básicos para conseguir el éxito de la osteosíntesis y evitar las con-

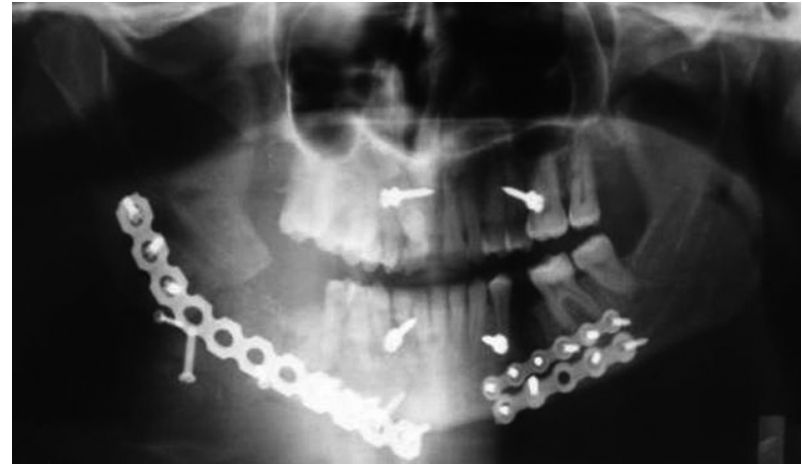

Figura 7. Ortopantomografía postquirúrgica. Se observa neoformación ósea.

Figure 7. Postoperative orthopantomography. Bone neoformation is evident.

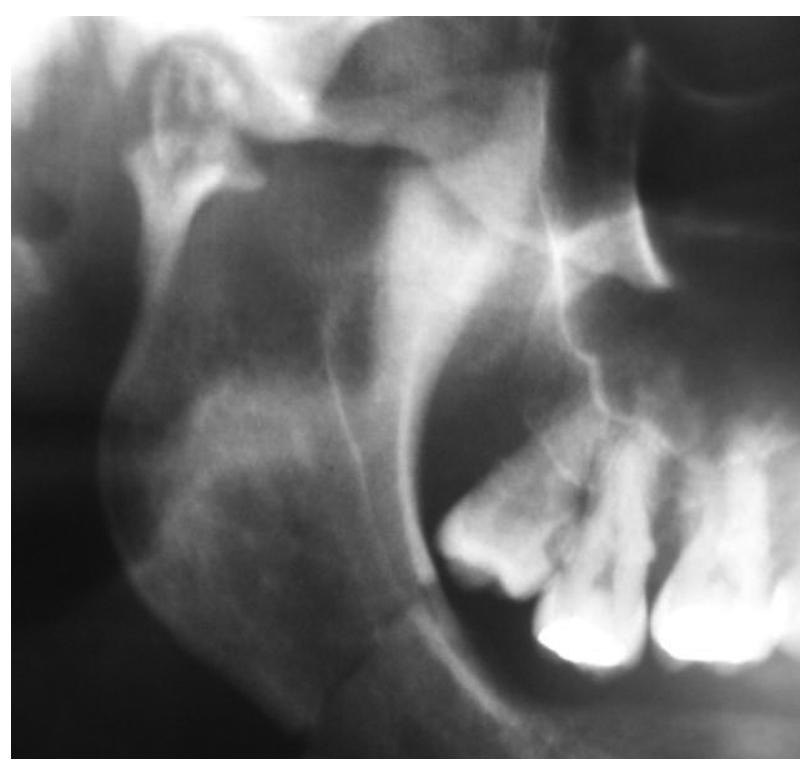

Figura 8. Fractura de ángulo derecho y subcondilea ipsilateral. Figure 8. Fracture of right mandibular angle and subcondylar area on the same side.

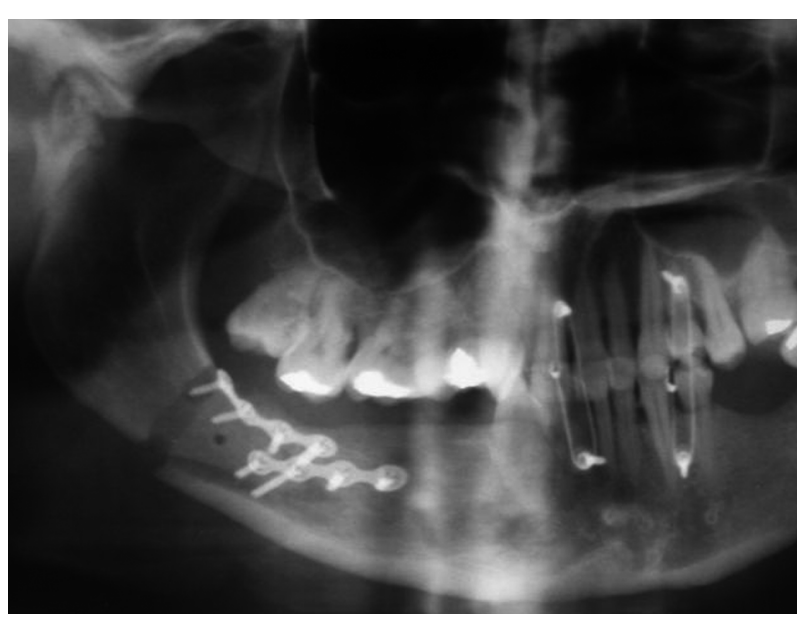

Figura 9. Ortopantomografía tras la primera cirugía. Figure 9. Orthopantomography after the first operation. without maxillomandibular fixation.

Five months later she had a new right osteosynthesis failure (Fig. 4). A new cervicotomy was made and a new osteosynthesis with a 2.4 "unilock" type reconstruction plate and autologous iliac crest graft was performed. The patient left the operating room with elastic maxillomandibular fixation (Figs. 5 and 6).

One year after the second operation, the fracture was perfectly consolidated. New bone formation was evident in the follow-up orthopantomography (Fig. 7).

Case 2

The patient was a 43-year-old woman, former smoker, with no other background of interest. She had bicondylar intracapsular fractures and a right angle mandibular fracture (Fig. 8).

Osteosynthesis with two miniature plates was performed on the mandibular angle. The two condylar fractures were treated by maxillomandibular fixation.

Three months later, the patient presented pseudoarthrosis of the right mandibular angle (Fig. 9). An extraoral approach was used to remove the plates and perform a new reduction and osteosynthesis with two 2.0 locking plates of different profiles and a particulate cancellous iliac crest graft (Figs. 10 and 11).

Six months after surgery there were no clinical manifestations suggestive of osteosynthesis failure (Fig. 12).

\section{Discussion}

The old concept of treating fractures by simple apposing 
secuencias nocivas de la inmovilización.

En lo referente a la técnica poco traumática, el empleo de un abordaje adecuado y la utilización de osteosíntesis que no comprima al hueso son las medidas más importantes. En este sentido, el advenimiento de las placas de osteosíntesis tipo "lock", 6 o bloqueado, permite conseguir uniones rígidas sin comprimir el hueso en curación. Así, las fuerzas de carga se transmiten desde el hueso a los tornillos y del tornillo a la placa. Con la redistribución de fuerzas entre el hueso y la placa, el tejido óseo sufre menor compresión, su vascularización se ve menos comprometida y el éxito de la osteosíntesis es mayor. Estas placas fueron sistemáticamente empleadas para el tratamiento del fracaso en los casos aquí expuestos.

Así, la primera paciente presentó un fracaso de la osteosíntesis en dos ocasiones.

Hubiera sido necesaria una fijación más rígida por presentar dos focos de fractura distintos y un bloqueo intermaxilar, por ser poco colaboradora debido a su patología de base.

La segunda paciente tenía tres fracturas. Cuando se presentan distintos focos, el brazo de palanca de la mandíbula cambia y es necesario, en al menos uno de los focos, una fijación más rígida (Fig. 13). ${ }^{7}$ La osteosíntesis fracasó por tratar una situación de carga soportada como carga compartida, o lo que es lo mismo, por realizar una osteosíntesis insuficiente para las características de esta fractura en particular.

Dentro del epígrafe de la téc-

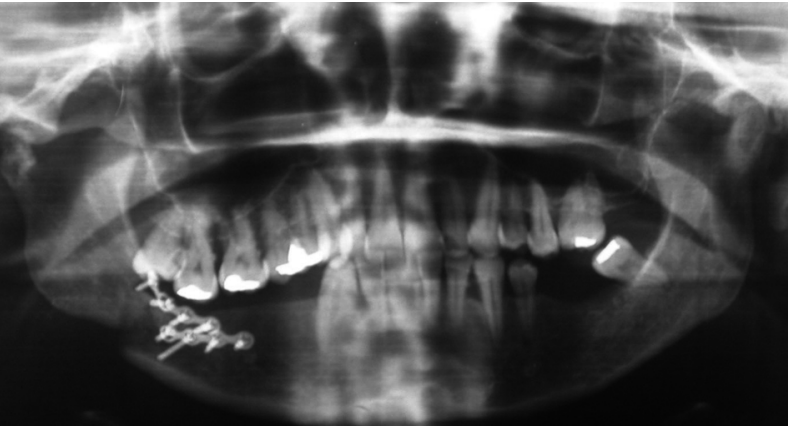

Figura 10. Fracaso de la osteosíntesis 3 meses después.

Figure 10. Osteosynthesis failure 3 months later.

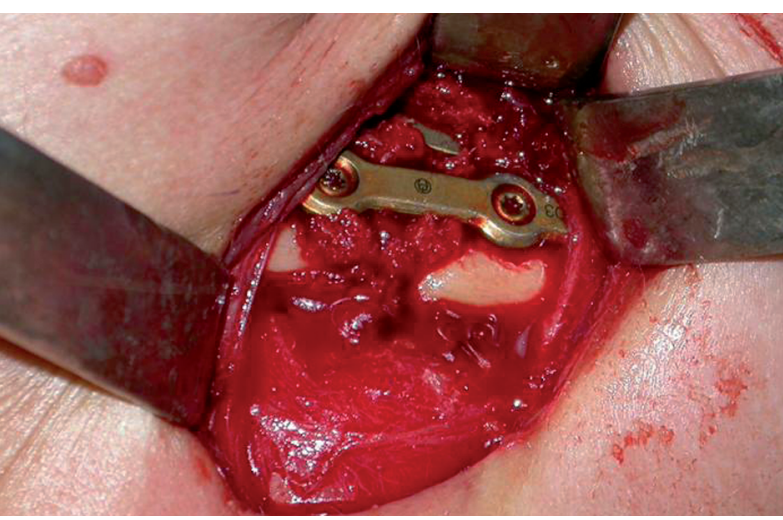

Figura 11. Osteosíntesis con placas tipo "lock" de 2,0 mm de distinto perfil junto a chips autólogos de cresta iliaca.

Figure 11. Osteosynthesis with $2.0 \mathrm{~mm}$ locking plates of different profiles and autologous iliac crest chips.

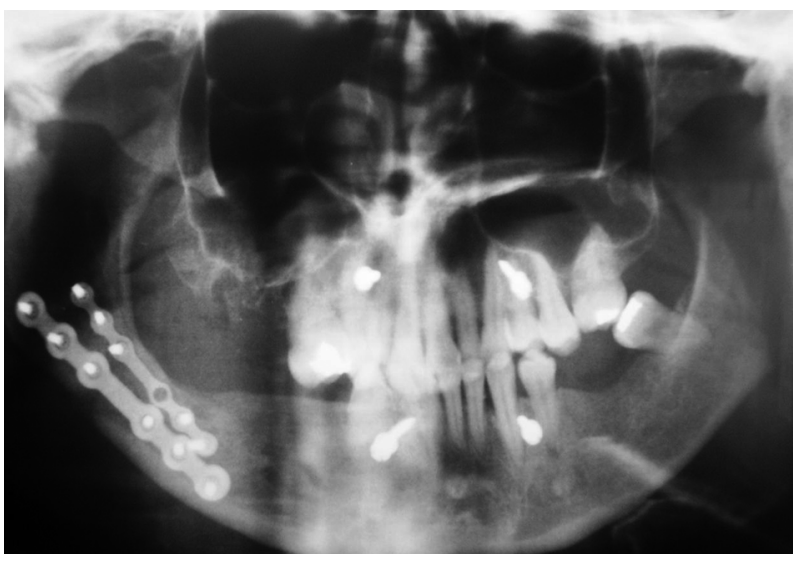

Figura 12. Ortopantomografía postoperatoria. Figure 12. Postoperative orthopantomography. the bone fragments is now considered outmoded in most fields of traumatology.

Four objectives of the treatment of mandibular fractures were cited in the introduction. The first two, anatomically correct reduction and adaptation of the osteosynthesis to the biomechanical characteristics of the system, have already been outlined.

The last two objectives, minimally traumatic technique and early rehabilitation, are two mainstays for achieving successful osteosynthesis and preventing the deleterious consequences of immobilization.

The use of a suitable approach and osteosynthesis that does not compress the bone are the most important measures for ensuring minimally traumatic technique. The development of locking type osteosynthesis plates 6 or blockade makes it possible to achieve resistant unions without compressing the healing bone. Such devices transmit the load forces from the bone to the screws and from the screw to the plate. By redistributing the forces between the bone and plate, the bone tissue suffers less compression and less vascular compromise, thus contributing to successful osteosynthesis. Osteosynthesis plates were used to treat failure of fracture union in the cases reported here.

The first patient experienced osteosynthesis failure on two occasions.

More rigid fixation was needed because the patient had two different fracture loci. In addition, maxillomandibular blockade was necessary because the patient was not very cooperative due to her underlying pathology.

The second patient had three fracnica quirúrgica adecuada, podemos incluir la utilización juiciosa de los injertos autólogos de hueso esponjoso (cresta ilíaca). Este tipo de injerto presenta células mesénquimales primitivas y progenitoras endoteliales que resisten muy bien la isquemia induciendo la neovascularización y osteoformación primitiva en el foco de la fractura. ${ }^{8}$ Una fijación rígida del injerto asegura una buena vascularización y una adecuada compresión para evitar la reabsorción ósea.

\section{tures. When more than one locus is involved, the mandibu-} lar lever forces changes and more rigid fixation is required in at least one focus (Fig. 1).? Osteosynthesis failed because the situation was a combination of load supporting and load sharing, making osteosynthesis insufficient for the characteristics of the particular fracture.

Proper surgical technique includes the judicious use of autologous cancellous bone grafts (iliac crest). This type 
Finalmente, la rehabilitación precoz, facilitada por la correcta osteosíntesis, evita la llamada "enfermedad de la fractura", consistente en una disminución del rango de movilidad mandibular tras un traumatismo. ${ }^{9}$ La inmovilización mediante bloqueos intermaxilares es perjudicial para todos los elementos del sistema estomatognático: hueso, músculo y articulación temporo-mandibular. ${ }^{10}$

\section{Conclusiones}

Para evitar fracasos en la osteosínesis mandibular, es necesario conocer las características biomecánicas del sistema.

La mayor parte de las veces se produce un fracaso de la osteosíntesis por tratar situaciones en las que es necesario carga soportada con carga compartida o, lo que es lo mismo, por utilizar fijación funcionalmente estable en vez de fijación rígida.

La utilización de placas tipo "lock" (fijador interno-externo) asegura un menor daño tisular al compartir la placa y el hueso las fuerzas de carga.

En caso necesario, se deben utilizar injertos óseos esponjosos obtenidos de cresta ilíaca del propio paciente.

\section{Bibliografía}

1. Moore Gf, Olson TS, Yonkers AJ. Complications of mandibular fractures: A retrospective review of 100 fractures in 56 patients. Nebr Med / 1985;70:120.

2. Fonseca RJ, Walter RV, Betts NJ. Mandibular fractures. Oral Maxillofacial Trauma. 2nd ed, 1997.

3. Champy M. y cols. Mandibular osteosynthesis by miniature screwed bone plates via a buccal approach. J Maxillofacial Surgery 1978;6:14.

4. Ellis E. Treatment of mandibular fractures using the AO reconstruction plate. I Oral Maxilofac Surg 1993;51:250.

5. Del Castillo JL, Demaría G, Arias J. Principios Básicos de Osteosíntesis. Manual de Traumatología Facial. 2007.

6. Alpert B, Gutwald R, Schmelzeisen R. New innovation in craniomaxillofacial fixation: the 2.0 lock system. The Keio Journal of Medecine 2003;52:120-7.

7. Passeri LA, Ellis E, Sinn DP. Complications of nonrigid fixation of mandibular angle fractures. J Oral Maxillofac Surg 1993;51:382.

8. Ochandiano S, Navarro Vila C. Bases biológicas del injerto óseo. Tratado de Cirugía Oral y Maxilofacial. 2004.

9. Cebrián y cols. Desarrollo de un simulador estático para estudios biomecánicos fotoelásticos del sistema músculo-esquelético masticatorio. Resúmenes y actas de del XVI Congreso Nacional de Ingeniería Mecánica. León. Diciembre, 2004.

10. Ellis III E, Carlson DS. The effects of mandibular immobilization on the masticatory system. A review. Clin Plast Surg 1989;16:133-46. of graft has primitive mesenchymal cells and endothelial stem cells that resist ischemia well, stimulating neovascularization and primitive osteoformation in the fracture locus. 8 Rigid fixation of the graft ensures good vascularization and adequate compression to prevent bone resorption.

Finally, early rehabilitation facilitated by correct osteosynthesis prevents socalled "fracture disease," which consists of a reduction in the range of mandibular mobility after an injury.9 Immobilization by maxillomandibular fixation is harmful for all the elements of the mouth and jaw: bone, muscle, and the temporo-mandibular joint. ${ }^{10}$

\section{Conclusions}

In order to avoid mandibular osteosynthesis failures, it is necessary to understand the biomechanical characteristics of the system.

Osteosynthesis failure occurs most often in situations in which both load supporting and load sharing are required, meaning that functionally stable fixation is needed instead of rigid fixation.

The use of locking plates (internal-external fixation) produces less tissue damage because the loading forces are shared by the plate and bone.

When needed, cancellous bone grafts harvested from the patient's own iliac crest should be used. 